\title{
KTO OSTÁVA A KTO ODCHÁDZA? MIGRAČNÉ ROZHODOVANIE ABSOLVENTOV ŽILINSKEJ UNIVERZITY V ŽILINE
}

\author{
Štefan Rehák*, Ivana Dudová** \\ * Ekonomická univerzita v Bratislave, NHF, Katedra verejnej správy a regionálneho rozvoja, \\ stefan.rehak@euba.sk \\ ** Žilinská univerzita v Žiline, FPEDAS, Katedra spojov, ivana.dudova@fpedas.uniza.sk
}

\begin{abstract}
Who stays and who leaves? Migration decision of the graduates from the Žilina University in Žilina

Higher education institutions raise the level of human capital in the region, but the contribution of the individual university on regional human capital depends on the migration of its graduates. This article analyses the relationship between the domicile, the location of university studies and location of employment. We examined the factors that influence the decision to stay at the university region after graduation. The analysis was based on data from the questionnaire survey of two cohorts of graduates of the Žilina University in Žilina. Approximately $87 \%$ of resident graduates and $21 \%$ of non-resident graduates remained in the university region after completing their studies. Using logistic regression, we analysed the factors that influence the migration decision of university graduates. Our research has confirmed the impact of wage levels on the migration decision. In addition, we also found the importance of gender, the study programme and the form of study on the migration decision. The magnitude of the impact of these factors varies depending on the residence of the graduate when entering university.
\end{abstract}

Key words: university graduates, migration, higher education, human capital, Žilina University in Žilina

\section{ÚVOD}

Vysoké školy majú v ekonomike tri hlavné úlohy. Prvou je generovanie l’udského kapitálu prostredníctvom vysokoškolského vzdelávania. Druhou úlohou je zvyšovanie technologickej a inovačnej úrovne firiem realizáciou výskumu. Nakoniec tret'ou úlohou je ich aktívne angažovanie v regionálnom rozvoji s ciel'om zvýšit' príspevok vysokých škôl k ekonomickému, sociálnemu a environmentálnemu rozvoju. Podl'a Faggian et al. (2017) je práve vzdelávanie najvýznamnejší faktor, ktorým školy vplývajú na rozvoj regiónu. Jednotlivci s vyšším vzdelaním sú nositel'mi nových znalostí a následne tvorcami nových nápadov a firmy, ktoré ich zamestnajú, sú produktívnejšie. Vyššia miera produktivity firiem v dôsledku l'udského kapitálu sa následne odzrkadlí vo vyššej miere ekonomického rastu, a to najmä v dlhodobom časovom horizonte (Romer 1986). Navyše koncentrácia l'udského kapitálu v mestách, resp. mestských regiónoch, zvyšuje produktivitu firiem prostredníctvom „priesakov“ znalostí (Glaeser et al. 1992 a Rauch 1993).

Vzt'ah medzi vysokoškolským vzdelávaním a akumuláciou l’udského kapitálu v regióne však nie je priamočiary. Ked’že jednotlivci s vyšším vzdelaním sú vel'mi mobilní, tak miera, do akej vzdelávanie poskytované univerzitou prispieva k rozvoju l'udského kapitálu hostitel'ského regiónu, závisí od schopnosti prilákat' do regiónu študentov a následne v ňom udržat' absolventov po skončení školy. 
Slovensko je krajinou, kde problematika vysokoškolského vzdelávania patrí medzi často diskutované a analyzované témy. Na Slovensku nastal pomerne vel'ký rozmach vysokého školstva spojený s nárastom počtu študentov z dôvodov vyššej participácie na vzdelávaní. Na jednej strane sa výskum v Slovenskej republike (SR) zameral na popísanie geografických aspektov procesu distribúcie vysokých škôl a dochádzky ich študentov. Od roku 1990 sa počet vysokých škôl na trhu zvýšil z 20 na 36 a zároveň narástol aj počet lokalít, kde je možné na vysokej škole študovat' z 11 na 18 miest (Rehák et al. 2015). Výsledkom je, že nastáva decentralizácia vysokého školstva, čo sa prejavuje $\mathrm{v}$ poklese počtu študentov dochádzajúcich zo vzdialenejších regiónov (Gurňák et al. 2011). Komplexný pohl'ad na tému rozvoja školstva a špecificky aj vysokého školstva sumarizovali Lauko et al. (2011). Na druhej strane sa výskum v SR zameral na migráciu jednotlivcov s vysokoškolským vzdelaním. Výskum v tejto oblasti ukázal, že existuje pomerne rozsiahla migrácia vysokoškolsky vzdelaných obyvatel'ov, ktorá je orientovaná hlavne do najväčších miest a $\mathrm{v}$ rastúcej miere $\mathrm{k}$ nej dochádza práve $\mathrm{z}$ pracovných dôvodov (Śprocha 2011). Výsledkom je, že napriek lepšej dostupnosti vysokoškolského štúdia v SR čelia zaostávajúce regióny emigrácii vysokoškolsky vzdelaného obyvatel'stva, čo má negatívne konzekvencie vzhl'adom na možnosti ich budúceho rozvoja (Novotný a Pregi 2016).

Tento príspevok smeruje $\mathrm{k}$ prepojeniu dvoch okruhov diskusie o vysokom školstve v SR, teda vzt'ahu medzi výberom miesta vysokoškolského štúdia a následne migráciou vysokoškolsky vzdelaných obyvatel’ov. Na otázku, do akej miery je migrácia absolventov VS ovplyvnená miestom vysokoškolského štúdia, je problematické odpovedat' vzhl'adom na neexistenciu verejne dostupných štatistických údajov. Ciel'om článku je preskúmat' súvislosti medzi miestom vysokoškolského štúdia a miestom zamestnania, pričom sa zameriava na analýzu faktorov ovplyvňujúcich rozhodnutie ostat' pracovat' po skončení školy v mieste štúdia, resp. odíst' za prácou do iného regiónu. V prvej časti prezentujeme prehl'ad literatúry v oblasti faktorov, ktoré ovplyvňujú migračné rozhodovanie absolventov vysokých škôl (d'alej VŠ). Následne v druhej časti na základe údajov dotazníkového prieskumu absolventov Žilinskej univerzity v Žiline analyzujeme prostredníctvom logistickej regresie faktory vplývajúce na rozhodovanie o zotrvaní na pracovnom trhu v mieste štúdia. Na záver diskutujeme o výsledkoch výskumu a jeho implikácie z pohl'adu akumuláciu l'udského kapitálu v regióne vysokej školy.

\section{MIGRAČNÉ ROZHODOVANIE ABSOLVENTOV VYSOKÝCH ŠKÔL - TEORETICKÉ VÝCHODISKÁ A EMPIRICKÝ VÝSKUM}

Výskum v oblasti migrácie využíva prístupy a metódy, ktoré vychádzajú z rozličných vedeckých disciplín (ekonómie, geografie, demografie a sociológie). Samotný výskum sa uskutočňuje v rozdielnych priestorových dimenziách, využíva rôzne dlhé časové obdobia a dáva si nielen otázky súvisiace s faktormi vysvetl'ujúcimi migráciu, ale aj s dôsledkami migrácie pre regióny. Jednou z dôležitých oblastí migrácie je pracovná migrácia, teda migrácia, ktorá sa spája s pohybom pracovnej sily medzi jednotlivými trhmi práce v dôsledku rozdielov v mzdách. Vo všeobecnosti môžeme odlíšit' tri skupiny mechanizmov vysvetl'ujúcich medziregionálnu migráciu pracovnej sily, menovite nerovnovážny model, rovnovážny model a model l'udského kapitálu (McCann 2013). V tomto príspevku sa zaoberáme vzt'ahom medzi vzdelaním a migráciou, preto budeme nadväzovat' hlavne na model migrácie založenej na rozdieloch v l'udskom kapitáli. 
Jednotlivci investujú do vzdelania s ciel'om zvýšit' svoje zručnosti a vedomosti, teda budujú svoj l'udský kapitál. Investovaním do l'udského kapitálu očakávajú zvýšenie svojich príjmov v dlhodobom horizonte a nezanedbatel'ným benefitom je aj zvýšenie spokojnosti so samotnou prácou. V tomto článku sa zaoberáme tou čast'ou l'udského kapitálu, ktorý získavajú jednotlivci vzdelávaním na vysokej škole. Z pohl'adu teórie migrácie založenej na l'udskom kapitále sa absolvovaním vysokoškolského vzdelania jednotlivci snažia maximalizovat' svoje budúce príjmy (Sjaastad 1962 a Becker 1964). Ked'že pracovné miesta pre vysokoškolsky vzdelaných jednotlivcov sú koncentrované v priestore, majú vzdelaní jednotlivci vyššiu mieru migrácie, migrujú na dlhšie vzdialenosti a najmä do rozvinutejších regiónov. Tento koncept však nedostatočne vysvetl'uje migráciu do zaostalých regiónov s nižšími mzdami a vyššou mierou nezamestnanosti. Jednoduchý model založený na priemerných mzdách totiž zanedbáva iné faktory, akými sú napr. sociálne vzt'ahy, náklady na živobytie, vybavenost' regiónov a životné prostredie $\mathrm{v}$ regióne (Graves 1980 a Roback 1982).

Špecifickou oblast’ou výskumu migrácie jednotlivcov s vyšším vzdelaním je migrácia čerstvých absolventov VŠ. Tá sa najčastejšie analyzuje z pohl'adu súvislosti medzi pôvodným bydliskom študenta, miestom vysokoškolského štúdia a miestom prvej pracovnej pozície (Faggian et al. 2007a, Ahlin et al. 2014, Herbst et al. 2014, Bjerke a Mellander 2017, Crescenzi et al. 2017 a Ma et al. 2016). Faggian et al. (2007b) v tejto logike rozlišujú medzi piatimi typmi absolventov. Opätovný migrant (repeat migrant) je nerezidentný absolvent, ktorý po skončení školy migroval za prácou do d’alšieho regiónu. Takzvaný spätný migrant (return migrant) je nerezidentný absolvent, ktorý sa po štúdiu na VS mimo svojho bydliska vrátil pracovat' do domovského regiónu. Univerzitný imigrant (university stayer) je nerezidentný absolvent, ktorý po ukončení VŠ ostal pracovat' v mieste štúdia. Neskorý migrant (late migrant) je rezidentný absolvent, ktorý študoval v mieste svojho bydliska a po ukončení VS začal pracovat' v inom regióne. Nakoniec nemigrant (non migrant) je rezidentný absolvent, ktorý študoval v mieste svojho bydliska a ostal tam pracovat' aj po absolvovaní VŠ́.

Miesto štúdia na VŠ ovplyvňuje následné rozhodnutie o výbere miesta zamestnania. Študenti počas štúdia získavajú viacej informácií o lokálnom pracovnom trhu a zároveň si budujú lokálne sociálne vzt'ahy. Môžeme predpokladat', že čast' študentov ostane po absolvovaní štúdia pracovat' na lokálnom pracovnom trhu. Tento proces však nie je automatický a existujú dôležité rozdiely v migrácii absolventov VŠ, ktoré sú výsledkom individuálnych charakteristík jednotlivca, charakteristík VS a charakteristík regiónu, v ktorom sa škola nachádza.

Výskum v oblasti migrácie zvyčajne dokumentuje, že ženy vykazujú menšiu migračnú intenzitu pre vyššiu averziu k riziku. Faggian et al. (2007b) však na výskume rozdielov v migrácii absolventov VŠ medzi mužmi a ženami vo Vel'kej Británii zistili, že ženy migrujú vo vyššej miere ako muži. Tento rozdiel vysvetl'ujú väčšou motiváciou žien získat' lepšie pracovné miesto pre ich častú diskrimináciu na trhu práce. Rôznorodost' migračného správania mužov a žien sa však vo všeobecnosti zmenšuje a dokonca migrácia vyššie kvalifikovaných žien v niektorých krajinách prevyšuje migráciu mužov (Dumont et al. 2007). Vyšší vek absolventa a dlhší čas od absolvovania VŠ znižuje pravdepodobnost' migrácie (Haapanen a Tervo 2012). Migračné rozhodovania sú málokedy individuálne, ale ovplyvňujú ich sociálne väzby. Výskum vo Švédsku ukázal, že prítomnost' rodičov alebo súrodencov v regióne zvyšuje šancu migrácie absolventa do tohto regiónu (Berck et al. 
2016). Žitie v partnerskom zväzku znamená komplikovanejšie hl'adanie pracovných miest pre dvoch jednotlivcov súčasne, preto jednotlivci v partnerských zväzkov majú nižšiu mieru migrácie. Navyše, ak majú partneri deti, znižuje sa ich migrácia ešte viac, pretože sa snažia znížit' riziko adaptácie detí na nové prostredie (Krabel a Flöther 2014).

Rozdiely v migrácii sú aj medzi jednotlivými študijnými odbormi. Tie súvisia s distribúciou pracovných miest pre rôzne kvalifikácie a rozdielnou schopnost'ou zamestnat' sa. Najväčšie rozdiely v migrácii sú medzi absolventmi technických a spoločenských a humanitných vied (Krabel a Flöther 2014). Vplyv kvality univerzity nie je jednoznačný. Štúdia o vplyve kvality vysokej školy na následnú migráciu absolventov v Taliansku (Ciriaci 2014) ukázala, že vyššia kvalita univerzity sa spája s vyššou pravdepodobnost'ou, že študent ostane pracovat' v mieste štúdia. Naopak, výsledky v Spojenom král'ovstve (Kidd et al. 2014) poukazujú na to, že vyššia kvalita univerzity sa spája s vyššou migráciou za prácou do iných regiónov. Výsledný vplyv kvality univerzity sa líši v závislosti od miery rozvinutosti regiónu. Ma et al. (2017) na štúdii v Južnej Kórei zistili, že v prípade menej rozvinutých regiónov je vyššia kvalita univerzít spojená s vyššou emigráciou absolventov.

Ahlin et al. (2014) na základe migrácie absolventov vo Švédsku ukázali, že dvaja z troch absolventov univerzít migrujú na vel'ké pracovné trhy, ktoré ponúkajú tzv. mestskú mzdovú prémiu. Tá je výsledkom vyšších počiatočných miezd, rýchlejšieho rastu miezd a príležitostí zmenit' zamestnanie v prvých rokoch (Ahlin et al. 2014). Vplyv vel'kosti pracovného trhu potvrdili aj Venhorst et al. (2011) pre Holandsko a Buensdorf et al. (2015) pre Nemecko.

\section{POUŽITÉ ÚDAJE A METÓDY}

$\mathrm{Na}$ Slovensku sa migrácia zvyčajne vymedzuje ako zmena obce trvalého pobytu (resp. mestskej časti) a typicky sa skúma na základe údajov z evidencie vnútorného st’ahovania. Tá vychádza z údajov z hlásenia o st'ahovaní, ktoré okrem predchádzajúceho a nového trvalého pobytu uvádza aj vybrané demografické ukazovatele. Ako konštatuje Bezák (2006), tento systém prináša problémy najmä pri rozdieloch medzi trvalým pobytom a miestom obvyklého pobytu. Pre náš výskum nie je evidencia vnútorného st'ahovania vhodným zdrojom údajov, ked’že neobsahuje údaj o mieste štúdia a ani o mieste pracoviska jednotlivca. Údaje pre tento výskum sme preto získali z dotazníkového prieskumu absolventov Žilinskej univerzity v Žiline. Žilinská univerzita je piata najväčšia univerzita v SR s počtom absolventov 2294 v roku 2016. Univerzita sa skladá z ôsmich fakúlt, ktoré sú prevažne technického zamerania. Dotazníkový prieskum sa uskutočnil v mesiacoch júl a august 2016 prostredníctvom on-line prieskumu absolventov. Aby sme mali možnost' porovnat' rozhodovanie čerstvých absolventov a absolventov, ktorí ukončili štúdium dávnejšie, sledovali sme dve kohorty absolventov. Prvá predstavovala tých, ktorí ukončili vysokú školu v školskom roku 2010/2011, a druhá absolventov zo školského roku 2015/2016. Základný súbor tvorilo 5166 absolventov. Dotazník vyplnilo spolu 1289 respondentov, čo predstavuje 25 \% návratnost'. Pre účely tohto článku sme pracovali len s absolventmi druhého stupňa štúdia, pretože absolventi prvého stupňa prevažne pokračujú vo vysokoškolskom štúdiu. Po vyčistení neúplne vyplnených dotazníkov predstavuje naša vzorka 633 respondentov. Ked’že bol dotazník verejne dostupný, vyplnili ho aj absolventi iných ročníkov. Preto sme vytvorili kategórie absolvent do dvoch rokov od ukončenia štúdia a ostatní absolventi. 
Analýza pracovnej migrácie sa zvyčajne skúma na úrovni priestorových jednotiek, ktoré reprezentujú jednotlivé pracovné trhy. Pre náš výskum používame tzv. aproximované funkčné regióny navrhnuté Halásom et al. (2014). Tie predstavujú agregované okresy do 47 kvázi funkčných regiónov, tak, aby bola maximalizovaná miera podobnosti s funkčnými regiónmi, teda regionálnymi trhmi práce. Potenciálny pracovný trh absolventov Žilinskej univerzity v Žiline v našom prípade predstavoval funkčný región, ktorý zahŕňa okresy Žilina, Kysucké Nové Mesto a Bytča.

Zaujíma nás vzt'ah medzi vzdelaním a migráciou, ktorý z priestorového pohl'adu analyzujeme ako súvislost' medzi miestom bydliska, miestom štúdia na vysokej škole a miestom pracoviska. Migráciu chápeme ako presun pracovnej sily medzi jednotlivými trhmi práce. V prípade čerstvých absolventov však ide o rozhodnutie pri prvom vstupe na pracovný trh, čo mierne odlišuje náš výskum od tradičného výskumu migrácie už zamestnanej pracovnej sily. V tomto článku modelujeme migračné rozhodovanie absolventa ako rozhodovanie ostat' pracovat' na trhu práce v mieste štúdia VŠ, alebo odíst' pracovat' inam. V skutočnosti je tento proces spojený s d'alšími priestorovými pohybmi jednotlivcov tak počas štúdia, ako aj po jeho absolvovaní. Patria sem napríklad dochádzanie do miesta vysokoškolského štúdia $\mathrm{z}$ miesta bydliska alebo dochádzanie do zamestnania $\mathrm{z}$ miesta bydliska. Tie však bližšie v tomto článku neskúmame.

Rozhodnutie ostat' pracovat' po ukončení štúdia v regióne, kde absolvent študoval, sme analyzovali prostredníctvom série otázok. Tie boli zamerané na oblast' štúdia, súčasnú ekonomickú aktivitu absolventa a individuálne charakteristiky respondenta. Pre účely regresnej analýzy sme z dotazníkového prieskumu vybrali dvanást’ premenných. Prvá skupina sa týkala premenných charakterizujúcich absolvované štúdium. V rámci tejto skupiny sme sledovali študijný odbor, formu štúdia, čas od ukončenia štúdia a študijné výsledky. Druhá skupina faktorov boli individuálne charakteristiky respondenta - pohlavie, rodinný stav a vzdelanie rodičov. Tretia skupina premenných sa týkala súčasnej ekonomickej aktivity absolventov. Do regresnej analýzy sme zaradili absolventov, ktorí v súčasnosti bud' pôsobia ako zamestnanci, alebo podnikajú. Zároveň sme sledovali ich pracovné skúsenosti v žilinskom regióne počas vysokoškolského štúdia. Štvrtá skupina predstavuje faktory týkajúce sa bydliska absolventa a regiónu, v ktorom sa zamestnal, resp. v ktorom podniká. Na základe bydliska absolventa $\mathrm{v}$ čase nástupu na vysokú školu sme rozdelili absolventov na rezidentných a nerezidentných. Takisto sme sledovali vzdialenost' pôvodného bydliska od vysokej školy a výšku mzdy v mieste pracoviska. Základné charakteristiky a popisné štatistiky premenných uvádzame v tab. 1.

Našou referenčnou kategóriou je slobodný muž s rodičmi, ktorí nemajú vysokú školu, bývajúci pri nástupe na vysokú školu mimo Žiliny. Študoval v dennej forme odbor technického alebo prírodovedného zamerania, absolvoval školu pred menej ako dvoma rokmi, bol priemerný, resp. podpriemerný študent. Mal rozsiahle pracovné skúsenosti počas štúdia a v súčasnosti je zamestnancom.

Zhodnotenie vplyvu faktorov na rozhodovanie o výbere pracovného miesta v regióne vysokoškolského štúdia, resp. presunom za prácou mimo regiónu, opierame o logistický model, kde závislou premennou je binárna premenná ostat', resp. odíst' za prácou mimo regiónu. Ide o tzv. departure model migrácie, v ktorom skúmame faktory ovplyvňujúce migračné rozhodnutie ostat', resp. odíst' z regiónu. Našu vzorku rozdel'ujeme a následne analyzujeme v štyroch modeloch. Prvý model (model 1) analyzuje celú vzorku absolventov. Druhý model (model 2) skúma roz- 
hodovanie rezidentných absolventov. Tretí model (model 3a) analyzuje rozhodovanie nerezidentných absolventov a štvrtý model (model 3b) rozhodovanie tých nerezidentných absolventov, ktorí sa nezamestnali po ukončení VŠ v domovskom regióne.

Tab. 1. Zoznam vysvetl'ujúcich premenných a ich popisná štatistika

\begin{tabular}{|c|c|c|c|c|c|c|c|}
\hline \multirow{2}{*}{ Premenná } & \multirow{2}{*}{ Popis a kódovanie } & \multicolumn{3}{|c|}{$\begin{array}{l}\text { Odišiel za prácou (0) } \\
\qquad(\mathrm{N}=380)\end{array}$} & \multicolumn{3}{|c|}{$\begin{array}{l}\text { Ostal pracovat' v Žiline (1) } \\
(\mathrm{N}=253)\end{array}$} \\
\hline & & Min & Max & Priem. & Min & Max & Priem. \\
\hline Študijný odbor & $\begin{array}{l}\text { Ktorý študijný odbor ste ukončili? } \\
\text { Technické a prírodovedné (0) Spolo- } \\
\text { čenské a humanitné (1) }\end{array}$ & 0 & 1 & 0,22 & 0 & 1 & 0,31 \\
\hline Forma štúdia & $\begin{array}{l}\text { V akej forme ste ukončili štúdium? } \\
\text { Denná forma (0) Externá forma (1) }\end{array}$ & 0 & 1 & 0,14 & 0 & 1 & 0,13 \\
\hline Čerstvý absolvent & $\begin{array}{l}\text { Kedy ste ukončili štúdium? } \\
\text { Viac ako } 2 \text { roky od ukončenia štúdia } \\
\text { (0) Do } 2 \text { rokov od ukončenia (1) }\end{array}$ & 0 & 1 & 0,39 & 0 & 1 & 0,49 \\
\hline Študijné výsledky & $\begin{array}{l}\text { Aké boli vaše študijné výsledky } \\
\text { v porovnaní s ostatnými } \\
\text { spolužiakmi? } \\
\text { Priemerný a podpriemerný študent } \\
\text { (0) Významne lepši študent (1) }\end{array}$ & 0 & 1 & 0,15 & 0 & 1 & 0,21 \\
\hline $\begin{array}{l}\text { Ekonomická } \\
\text { aktivita }\end{array}$ & $\begin{array}{l}\text { Aká je vaša súčasná ekonomická } \\
\text { aktivita? } \\
\text { Zamestnanec (0) Podnikatel' (1) }\end{array}$ & 0 & 1 & 0,09 & 0 & 1 & 0,07 \\
\hline Pohlavie & $\begin{array}{l}\text { Vaše pohlavie? } \\
\text { Muž (0) Žena (1) }\end{array}$ & 0 & 1 & 0,24 & 0 & 1 & 0,47 \\
\hline Rodinný stav & $\begin{array}{l}\text { Aký je váš rodinný stav? } \\
\text { Slobodný (0) V partnerskom zväzku, } \\
\text { bývajúci v spoločnej domácnosti (1) }\end{array}$ & 0 & 1 & 0,35 & 0 & 1 & 0,43 \\
\hline Vzdelanie rodičov & $\begin{array}{l}\text { Má niektorý z vašich rodičov VŠ } \\
\text { vzdelanie? } \\
\text { Nie (0) Âno (1) }\end{array}$ & 0 & 1 & 0,28 & 0 & 1 & 0,37 \\
\hline $\begin{array}{l}\text { Pracovné } \\
\text { skúsenosti }\end{array}$ & $\begin{array}{l}\text { Pracovali ste počas štúdia v Žiline? } \\
\text { Rozsiahle pracovné skúsenosti (0) } \\
\text { Malé pracovné skúsenosti (1) }\end{array}$ & 0 & 1 & 0,40 & 0 & 1 & 0,28 \\
\hline Bydlisko & $\begin{array}{l}\text { Aké bolo vaše obvyklé bydlisko } \\
\text { v čase nástupu na vysokú školu? } \\
\text { Bydlisko mimo Žiliny (0) Bydlisko } \\
\text { Žilina (1) }\end{array}$ & 0 & 1 & 0,06 & 0 & 1 & 0,62 \\
\hline Vzdialenost' k VŠ & $\begin{array}{l}\text { Vzdialenost' centroidov } \\
\text { jednotlivých regiónov (km) }\end{array}$ & 0 & 261 & 83,4 & 0 & 211 & 24,5 \\
\hline Mzda - pracovisko & $\begin{array}{l}\text { Priemerná mesačná mzda v období } \\
2011-2015 \text { v mieste pracoviska } \\
\text { (eur) }\end{array}$ & 607 & 1219 & 946,2 & 916 & 916 & 916,0 \\
\hline
\end{tabular}

Zdroj: Vlastné spracovanie na základe údajov z dotazníkového prieskumu. Údaje o mzde v mieste pracoviska sú prepočty z databázy DATAcube ŠÚ SR (2017).

\section{VÝSLEDKY}

Hlavným ciel'om analýzy bolo zistit', ktoré faktory vplývajú na rozhodnutie, že absolventi vysokej školy ostanú po ukončení štúdia pracovat' v mieste štúdia. V dotazníkovom prieskume sme zist'ovali okres bydliska pred nástupom na vysokú 
školu a okres pracoviska po ukončení vysokej školy. Na základe toho sme rozdelili absolventov na rezidentných, ktorí bývali vo funkčnom regióne Žilina, a nerezidentných bývajúcich v ostatných častiach SR. Táto klasifikácia nám umožnila kategorizovat' absolventov do piatich skupín podl'a Faggian et al. (2007b).

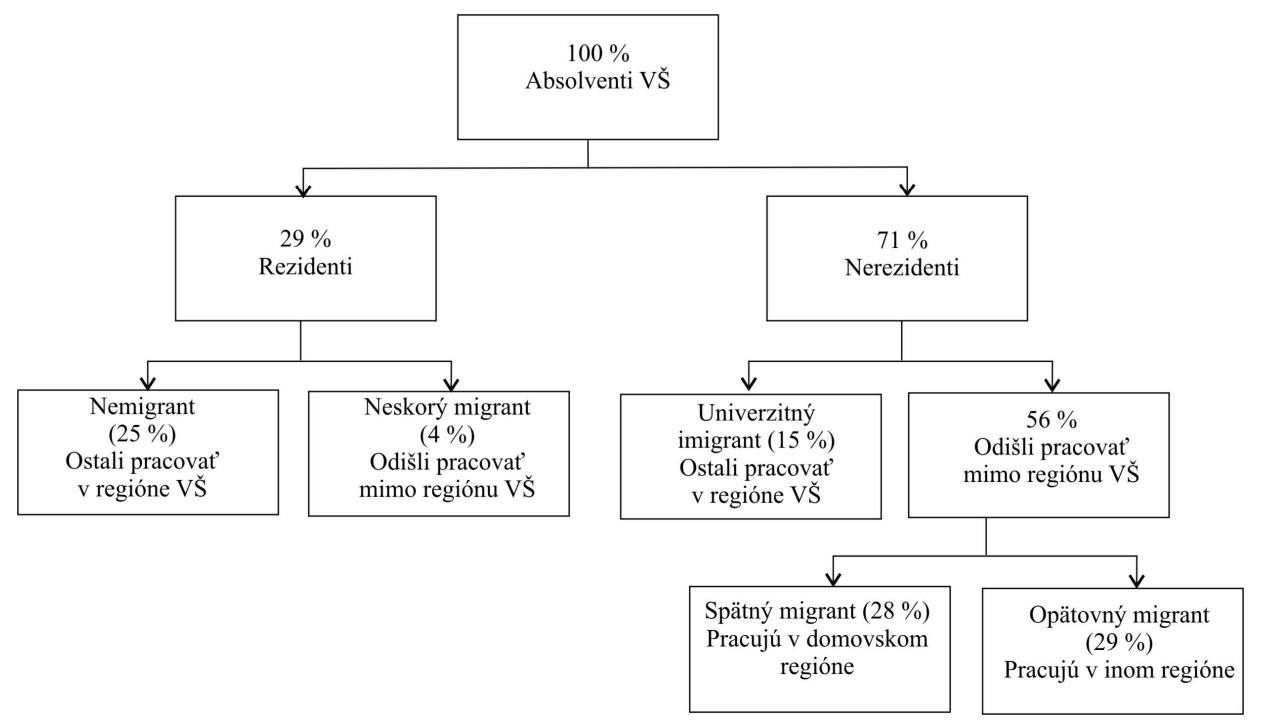

Obr. 1. Rozdelenie typov absolventov

Pozn.: Rozdiel v súčte na najnižšej hierarchickej úrovni je výsledkom zaokrúhl’ovania.

Zdroj údajov: dotazníkový prieskum.

Z pohl'adu bydliska pri nástupe na vysokú školu bolo $29 \%$ absolventov zo žilinského regiónu. Približne $13 \%$ z nich (4 \% z celkového počtu absolventov) odišlo za prácou mimo regiónu. $Z$ nerezidentných absolventov ostalo pracovat' vo vysokoškolskom regióne $21 \%$ (15\% z celkového počtu absolventov). Zo zvyšných nerezidentných absolventov asi polovica pracuje $\mathrm{v}$ domovskom regióne (28\% $\mathrm{z}$ celkového počtu absolventov) a polovica odišla za prácou do iného regiónu ( $29 \%$ z celkového počtu absolventov).

Uskutočnili sme aj podrobnejšiu analýzu bydliska a pracoviska absolventov Žilinskej univerzity v Žiline. Ako dokumentuje mapa (obr. 2), okrem absolventov zo žilinského regiónu univerzita vo väčšej miere získava študentov z jej najbližšieho okolia. Spolu 53,3 \% študentov pochádzalo zo žilinského regiónu a z územných celkov bezprostredne susediacich. Priemerná vzdialenost' bydliska od vysokej školy bola 59,9 km (medián 49,7 km).

Absolventi, ktorí ostali pracovat' v žilinskom regióne, tvorili až 40 \% respondentov. Z pohl'adu žilinského regiónu teda došlo k nárastu l'udského kapitálu. Priemerná vzdialenost' pracoviska od vysokej školy bola $62 \mathrm{~km}$ (medián $41 \mathrm{~km}$ ), čo dokumentuje, že vel'ká čast' absolventov odišla za prácou do vzdialenejších regiónov. Z tých absolventov, ktorí odišli za prácou mimo žilinského regiónu, najväčšia čast' pracuje v bratislavskom regióne (30 \%), druhým v poradí bol s výrazným odstupom trenčiansky región $(3,3 \%)$. 


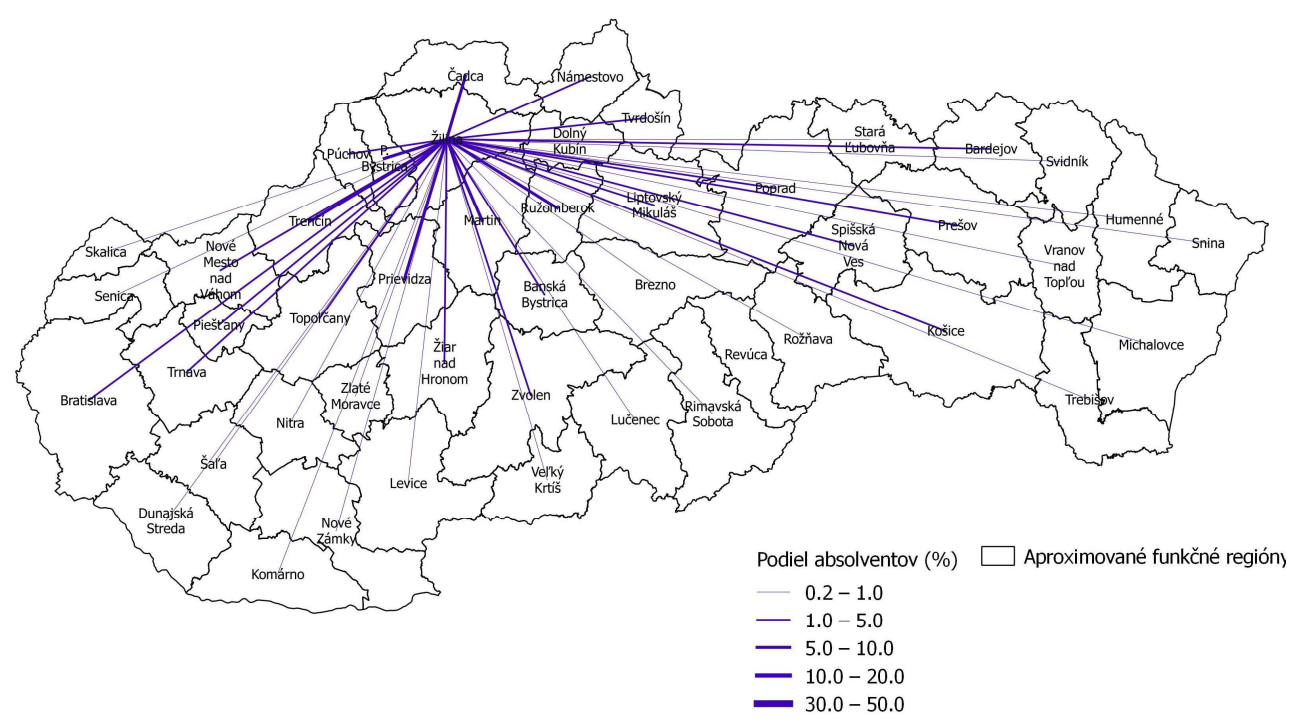

Obr. 2. Absolventi Žilinskej univerzity v Žiline z hl'adiska ich miesta bydliska v čase nástupu na VŠ

Zdroj: Vlastné spracovanie v programe QGIS na základe údajov z dotazníkového prieskumu.

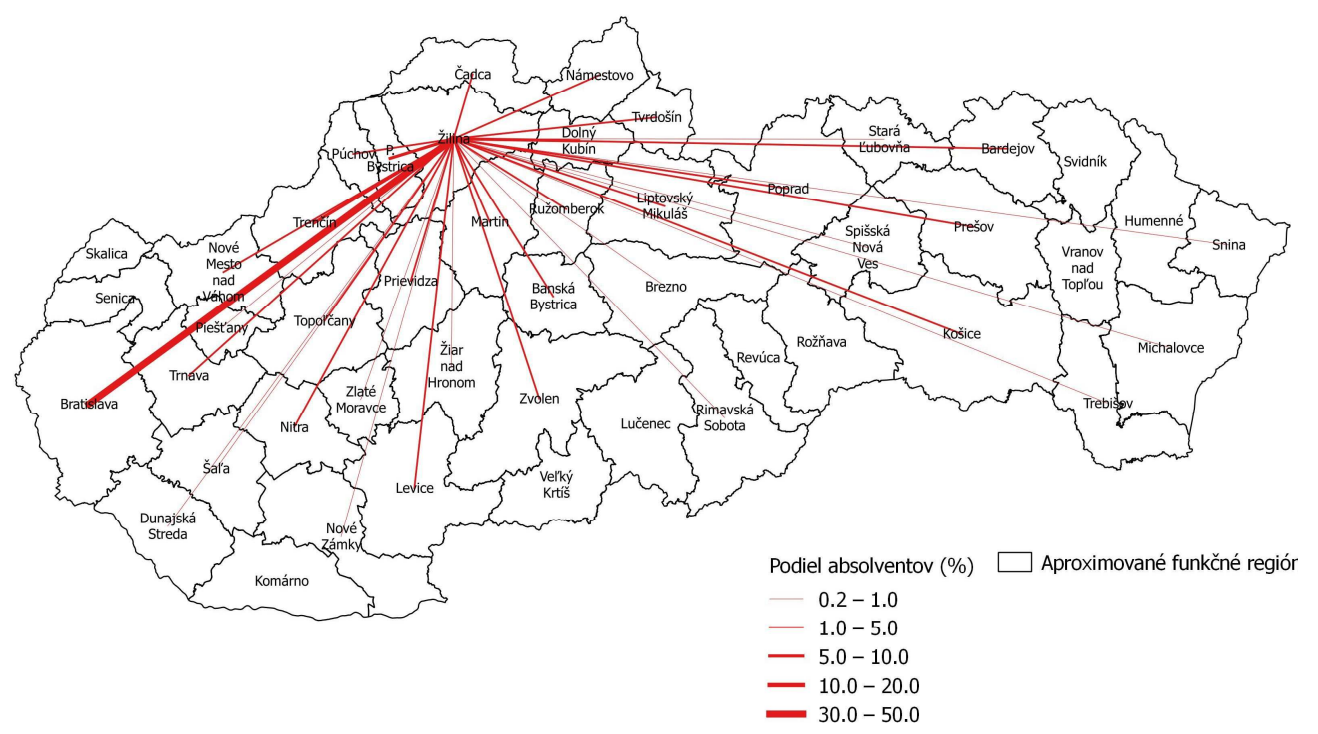

Obr. 3. Absolventi Žilinskej univerzity v Žiline z hl’adiska ich pracovného miesta po skončení VŠ

Zdroj: Vlastné spracovanie v programe QGIS na základe údajov z dotazníkového prieskumu.

Výsledky regresných analýz, ktoré identifikujú vplyv faktorov ovplyvňujúcich rozhodnutie ostat' pracovat' po ukončení štúdia v regióne vysokej školy, sú sumari- 
zované v tab. 2 a 3. Model 1 so všetkými zahrnutými respondentmi bol štatisticky signifikantný, čo indikuje, že bol schopný odlíšit' medzi respondentmi, ktorí ostali pracovat' $\mathrm{v}$ regióne (nemigranti a univerzitní imigranti) a tými, ktorí odišli za prácou mimo regiónu vysokoškolského štúdia (opätovní migranti, spätní migranti a neskorí migranti). Celkove model vysvetlil $37 \%$ variácie v migračnom rozhodovaní. Model správne klasifikoval $82 \%$ prípadov (s hraničnou hodnotou 0,5 ), čo je významne viac ako v prípade modelu bez zahrnutých premenných (60\%).

Ako vidíme $\mathrm{v}$ tab. 2, devät' $\mathrm{z}$ dvanástich premenných bolo štatisticky významných. Tri premenné neboli štatisticky významné: jednotlivci s lepšími študijnými výsledkami mali vyššiu šancu ostat' pracovat' v mieste štúdia, jednotlivci s bohatšími pracovnými skúsenost’ami v mieste vysokoškolského štúdia a podnikatelia mali naopak nižšiu šancu pracovat' v žilinskom regióne. Ženy, jednotlivci, ktorí žili v partnerskom zväzku v spoločnej domácnosti, a tí, ktorí pochádzali z rodiny s minimálne jedným rodičom s vysokoškolským vzdelaním, mali vyššiu šancu ostat' pracovat' $\mathrm{v}$ žilinskom regióne. Takisto jednotlivci, ktorí sú dva roky po ukončení štúdia alebo menej, a jednotlivci pochádzajúci zo žilinského regiónu mali vyššiu šancu zotrvat' v regióne. Absolvovanie štúdia v spoločenských a humanitných študijných odboroch a v externej forme zvyšovalo šancu odíst' za prácou mimo regiónu. Absolventi, ktorí pochádzali zo vzdialenejších regiónov a $\mathrm{z}$ regiónov s vyššou priemernou mzdou, mali vyššiu šancu odíst’ za prácou do iných regiónov. Spomedzi kategorických premenných malo najvýznamnejší vplyv, ak absolvent pochádzal zo žilinského regiónu. Respondenti majúci bydlisko v žilinskom regióne vykazovali približne 16-krát vyššiu pravdepodobnost', že v ňom ostanú po skončení štúdia pracovat', ako respondenti z iných regiónov. Pomer šancí vo výške 0,455 v prípade ukazovatel'a forma štúdia vyjadruje, že absolventi v externej forme štúdia mali 0,476-krát nižšiu šancu ostat' pracovat' v regióne v porovnaní s absolventmi denného štúdia.

Následne sme samostatne skúmali rozhodovanie rezidentných absolventov, teda absolventov, ktorí pochádzali zo žilinského regiónu (model 2), nerezidentných absolventov (model 3a) a špecificky tých nerezidentných absolventov, ktorí sa nevrátili do svojho domovského regiónu (model 3b). Model 2, ktorý analyzuje rozhodovanie rezidentných absolventov (nemigranti vs. neskorí migranti), vysvetloval $41,2 \%$ variácie $\mathrm{v}$ rozhodovaní, pričom správne klasifikoval až $94 \%$ prípadov. $\mathrm{V}$ porovnaní s modelom 1 sú v tomto modeli len tri premenné štatisticky významné. Študenti s lepšími študijnými výsledkami mali vyššiu šancu odíst' za prácou mimo regiónu. Šanca, že po skončení školy ostane absolvent pracovat' v žilinskom regióne, sa ukázala byt' vyššia u žien a tento faktor bol podstatne dôležitejší ako v modeli 1. Vyššia mzda v ciel'ovom regióne zvyšovala šancu odíst' za prácou.

$\mathrm{V}$ modeli 3a sme analyzovali rozhodovanie nerezidentných absolventov, teda tých, ktorých bydlisko pri nástupe na vysokú školu bolo mimo žilinského regiónu (univerzitní imigranti vs. spätní migranti a opätovní migranti). Kvalita tohto modelu bola významne nižšia v porovnaní s modelom 1 a aj v porovnaní s ostatnými modelmi. Model vysvetl'oval $11,9 \%$ variability a správne klasifikoval 80 \% prípadov. V modeli bolo šest' štatisticky významných premenných. Štúdium spoločenských a humanitných odborov, štúdium v externej forme a väčšia vzdialenost' bydliska od vysokej školy znižovali šancu ostat' pracovat' v regióne, čo je porovnatel'ný výsledok s modelom 1 . Tak ako v modeli 1 , ženy a jednotlivci, ktorí ukončili štúdium pred kratším časom, mali vyššiu šancu ostat' pracovat' v regióne. Navyše, lepšie študijné výsledky v tomto modeli znamenali vyššiu šancu zotrvat' v regióne. 
GEOGRAFICKÝ ČASOPIS / GEOGRAPHICAL JOURNAL 70 (2018) 1, 39-55

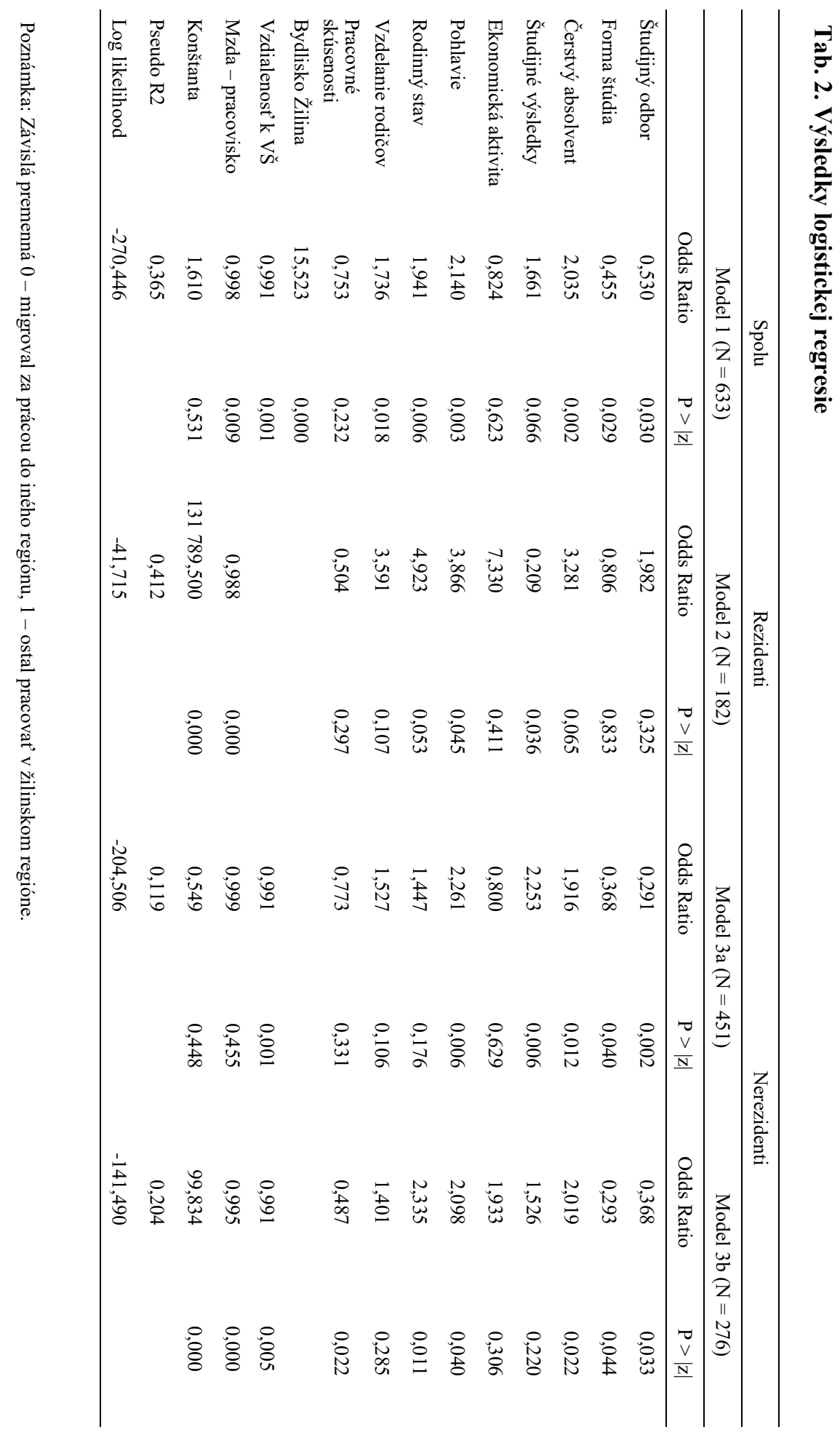


Aby sme odstránili vplyv potenciálnych sociálnych väzieb $\mathrm{k}$ bydlisku, ktoré sme v modeli neskúmali, vynechali sme v modeli 3b nerezidentných absolventov, ktorí sa vrátili do domovského regiónu (univerzitní imigranti vs. opätovní migranti). Model vysvetl'oval 20,4 \% variability a klasifikoval správne 70,7 \% prípadov. Osem premenných bolo štatisticky významných. V porovnaní s modelom 3a sme zistili, že študijné výsledky nie sú pre rozhodovanie štatisticky významné. Absolventi žijúci s partnerom v spoločnej domácnosti mali vyššiu šancu zotrvania v žilinskom regióne. Bohatšie pracovné skúsenosti v regióne počas štúdia znamenali vyššiu šancu ostat' pracovat' $v$ regióne. Väčšia vzdialenost' medzi bydliskom a vysokou školou, ako aj výška mzdy v mieste pracoviska zvyšovali šancu odchodu za prácou mimo regiónu.

Aby sme vedeli porovnat' relatívnu výšku vplyvu jednotlivých premenných na rozhodovanie absolventov, či zostanú pracovat' v žilinskom regióne, vypočítali sme $\mathrm{v}$ jednotlivých modeloch priemerné hraničné efekty. Výsledky uvádzané v tab. 3 ukazujú, že medzi jednotlivými modelmi sú významné rozdiely. V modeli 1 má najvýznamnejší vplyv na rozhodnutie to, či absolvent pochádzal zo žilinského regiónu. Tento faktor mal až 37-percentný vplyv na zvýšenie pravdepodobnosti zotrvania $\mathrm{v}$ regióne. Ďalšie dôležité faktory zvyšujúce pravdepodobnost' zotrvania V regióne boli: absolvent mal viac ako dva roky od ukončenia VŠ $(11 \%)$, absolventom bola žena $(10 \%)$ a absolvent žil v spoločnej domácnosti v partnerskom zväzku (9 \%). Faktory najviac znižujúce pravdepodobnost' zotrvania v regióne boli: externá forma štúdia $(-11 \%)$ a štúdium humanitných a spoločenských vied $(-9 \%)$. Výsledný hraničný efekt nárastu vzdialenosti medzi bydliskom a miestom vysokej školy o $1 \mathrm{~km}$ na pravdepodobnost' zotrvania na pracovnom trhu v žilinskom regióne bol vo výške $-0,12 \%$. Nárast vzdialenosti z minimálnej hodnoty $(0 \mathrm{~km})$ na maximálnu $(261 \mathrm{~km})$ znižuje celkový vplyv na pravdepodobnost' zotrvania vo výške $31 \%$. Nárast mzdy v mieste zamestnania o 1 euro znižuje pravdepodobnost' zotrvania $\mathrm{v}$ regióne o $0,03 \%$. Nárast mzdy z minimálnej hodnoty (607 eur) na maximálnu hodnotu (1 219 eur) znižuje pravdepodobnost' zotrvania v žilinskom regióne približne o $18 \%$.

Analýza priemerných hraničných efektov $\mathrm{v}$ modeli 2 ukázala, že faktory ovplyvňujúce rozhodovanie absolventov, sú významne odlišné v porovnaní s modelom 1. Len tri premenné sú štatisticky významné. Najvyšší vplyv mali lepšie študijné výsledky, ktoré znižovali pravdepodobnost' zotrvania v regióne o 10,3\%. Premenná ženské pohlavie znižovala pravdepodobnost' zotrvania o 8,9 \%, čo je však menej ako pri prvom modeli. Nárast mzdy mal v porovnaní s modelom 1 významne vyšší vplyv, pričom rast mzdy o 1 euro znižuje pravdepodobnost' zotrvania o $0,08 \%$.

Najvýznamnejší faktor, ktorý ovplyvňoval nerezidentných študentov v modeli 3a, bol študijný odbor. Absolvovanie humanitného alebo spoločenského odboru znižovalo pravdepodobnost' zotrvania v regióne o 17,9 \%. Podobne vysoký vplyv malo aj absolvovanie štúdia $\mathrm{v}$ externej forme, ktoré znižovalo pravdepodobnost' o 14,6 \%. Kratší čas od ukončenia štúdia, lepšie študijné výsledky a ženské pohlavie zvyšovali pravdepodobnost' zotrvania v žilinskom regióne. Zaujímavým zistením bol štatisticky nevýznamný faktor miezd v mieste pracoviska.

$\mathrm{V}$ modeli 3 b boli najvýznamnejšími faktormi, ktoré znižovali pravdepodobnost' zotrvania v mieste štúdia, absolvovanie humanitného a spoločenskovedného odboru (-17,2 \%) a externá forma štúdia (- 21,1 \%). Najvýznamnejšie faktory zvyšujúce 
GEOGRAFICKÝ ČASOPIS / GEOGRAPHICAL JOURNAL 70 (2018) 1, 39-55

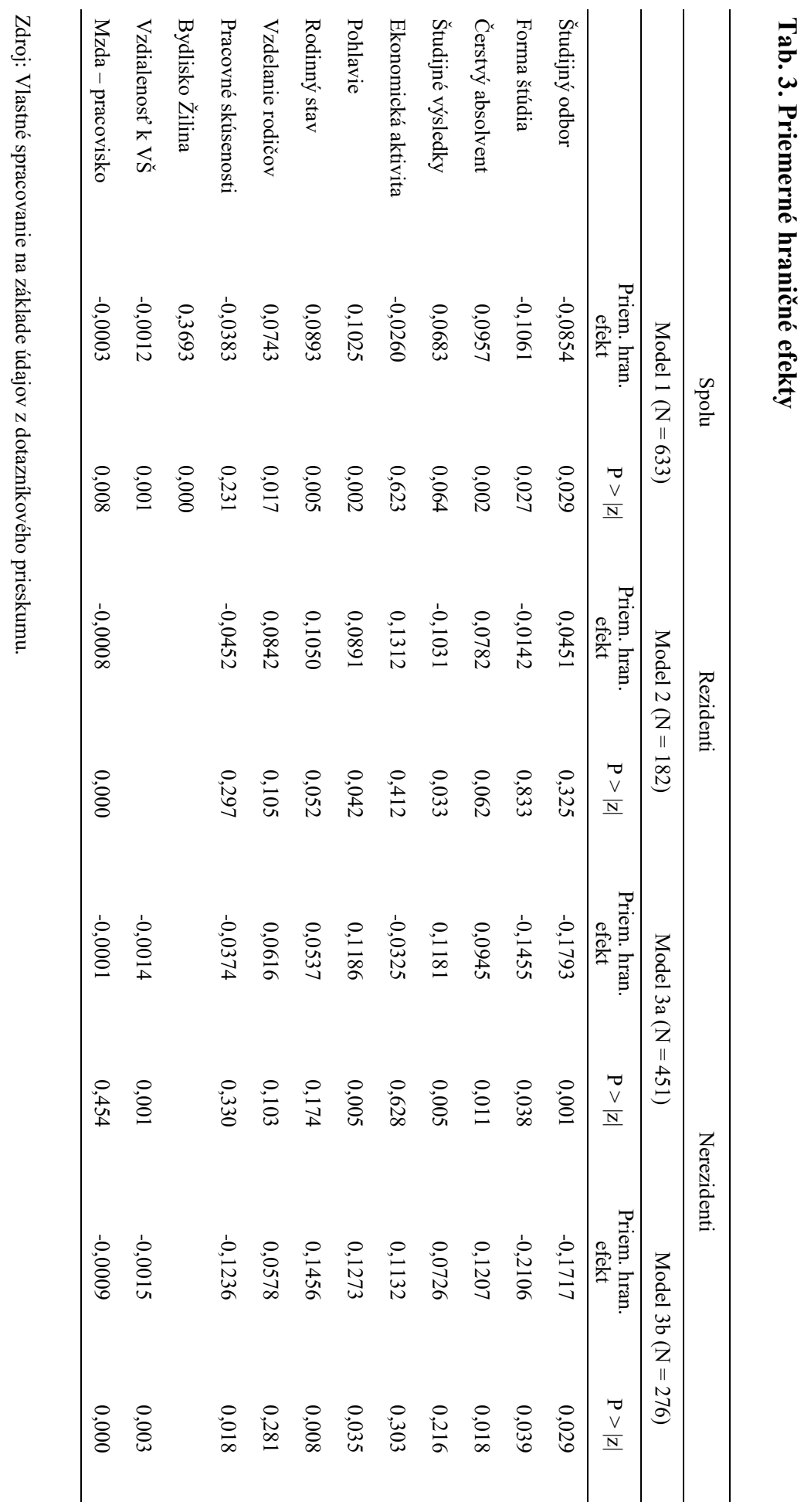


pravdepodobnost' zotrvania v mieste štúdia boli: partnerské spolužitie v spoločnej domácnosti $(14,6 \%)$, ženské pohlavie $(12,7 \%)$ a krátky čas od ukončenia štúdia $(12,1 \%)$. Oproti modelu 3 a bol faktor mzda v mieste pracoviska štatisticky významný a jeho hodnota bola porovnatel'ná s modelom 2 .

\section{DISKUSIA}

Príklad absolventov Žilinskej univerzity v Žiline ukázal, že podiel absolventov, ktorí ostali pracovat' v regióne (40 \%), je vyšší ako podiel absolventov bývajúcich v žilinskom regióne pred nástupom na VŠ (29\%). Prítomnost' vysokej školy v regióne zvyšuje akumuláciu l’udského kapitálu na trhu práce, čo potvrdzuje naše predpoklady z literatúry (Faggian et al. 2017). Podrobnejšia analýza charakteristík absolventov však ukázala, že tento mechanizmus je pomerne komplikovaný.

Okrem absolútneho počtu absolventov je dôležitým faktorom ich kvalita. Doterajší empirický výskum vplyvu študijných výsledkov absolventov na ich migračné rozhodovanie v zahraničí priniesol rozporuplné výsledky. Ciriaci (2014) zistila, že lepšie študijné výsledky absolventov v Taliansku zvyšujú šancu ostat' pracovat' v regióne VŠ, a naopak Kidd et al. (2017) konštatujú, že lepšie študijné výsledky absolventov v Spojenom král'ovstve znižujú šancu ostat' pracovat' v regióne. V našom výskume sa ukázalo, že celkovo bol vplyv študijných výsledkov štatisticky nevýznamný. Podrobnejšia analýza ale odhalila, že strata najlepších rezidentných absolventov je čiastočne kompenzovaná imigráciou nerezidentných študentov s lepšími študijnými výsledkami. Celkový únik mozgov v prospech najrozvinutejších regiónov teda nemusí byt' automatický. Aj výskum v Holandsku ukázal (Venhorst et al. 2010), že v prípade niektorých študijných odborov absolventi $\mathrm{s}$ najlepšími výsledkami ostávali pracovat' $\mathrm{v}$ periférnych regiónoch a nemigrovali do tých rozvinutejších.

Ďalším naším zistením bolo, že existuje súvislost' medzi miestom bydliska, miestom štúdia na vysokej škole a miestom pracoviska. Jednotlivci, ktorí študovali mimo svojho bydliska (nerezidentní študenti), majú vyššiu šancu rozhodnút' sa pracovat' $\mathrm{v}$ inom regióne oproti rezidentným absolventom. Naše výsledky sú v súlade so zisteniami predchádzajúcich empirických štúdií (napr. Faggian et al. 2007a, Herbst et al. 2014 a iní) a potvrdzujú, že migrácia má sekvenčný charakter (DaVanzo a Morrison 1981), teda, že predchádzajúca migrácia zvyšuje pravdepodobnost' následnej migrácie. Jednotlivci, ktorí študovali v inom regióne, boli vystavení psychickému zat’aženiu spojenému s odlúčením od rodiny a priatel'ov v domovskom regióne. Preto ich d'alšie rozhodovanie o migrácii po ukončení štúdia je jednoduchšie. Potvrdzuje to aj d'alší stabilný výsledok našej analýzy, podl'a ktorého väčšia vzdialenost' bydliska od miesta štúdia pri nástupe na VŠ zvyšuje šancu, že si absolvent vyberie pracovné miesto mimo regiónu vysokoškolského štúdia. Tento výsledok môže mat' aj širšie praktické implikácie pre regionálny rozvoj. Naša analýza indikuje, že čím viac má vysoká škola nerezidentných študentov a čím viac ich je zo vzdialených regiónov, tým je menšia šanca, že ostanú po skončení školy pracovat' na regionálnom trhu práce.

Výsledky všetkých modelov ukázali, že vyššie mzdy na ciel'ovom trhu práce zvyšujú šancu migrácie mimo regiónu vysokej školy. Investíciami do vzdelania narastá motivácia zhodnotit' nadobudnutý l’udský kapitál prostredníctvom migrácie do oblastí s vyššími mzdami, čo je v súlade s očakávaniami z pohladu teoretického konceptu migrácie l’udského kapitálu aj z pohl'adu empirických štúdií (Kidd et al. 
2014 a Ma et al. 2017). Význam vyšších budúcich príjmov však pravdepodobne znižujú sociálne väzby na rodinu, čo ukázala zmena štatistickej významnosti ukazovatel'a mzdy v modeli 3a.

Náš výskum tiež ukázal existenciu rodových rozdielov v migračných rozhodnutiach. Ženy majú vyššiu šancu zotrvat' v regióne vysokej školy po absolvovaní štúdia, pričom tento faktor bol jediný štatisticky významný vo všetkých modeloch. Migračné teórie zvyčajne tento argument vysvetl'ujú väčšou averziou žien k riziku, s ktorým je spojená migrácia za prácou. Výsledky autorov Ciriaci (2014) a Kidd et al. (2014) potvrdzujú náš záver, ked’že tiež zistili, že ženy viac ostávajú pracovat' v mieste štúdia. Menšia miera migrácie žien môže byt' vysvetlená aj vybudovaním intenzívnejších sociálnych väzieb v mieste štúdia. Dôležitost' sociálnych vzt'ahov potvrdil aj d'alší náš výsledok. Absolventi žijúci v partnerskom zväzku v spoločnej domácnosti migrujú menej často, pretože ich rozhodnutie zahŕn̆a zmenu pracovného miesta aj u partnera.

Absolventi spoločenských a humanitných vied vykazovali štatisticky významne vyššiu tendenciu migrovat' za prácou mimo žilinského regiónu v porovnaní s technickými a prírodovednými odbormi len $\mathrm{v}$ prípade nerezidentných jednotlivcov. Rozdiely v migrácii medzi odbormi sú zvyčajne zapríčinené rozdielmi v priestorovej distribúcii pracovných miest a mierou, $\mathrm{v}$ akej je štruktúra odborov absolventov univerzity v súlade s potrebami regionálneho trhu práce. Žilinský región sa špecializuje na priemyselnú výrobu a v posledných rokoch významne rástol dopyt po pracovnej sile v tomto sektore. Pracovné miesta pre absolventov spoločenských a humanitných vied sú ovel’a menej koncentrované a sú k dispozícii aj v ostatných regiónoch SR. Tento výsledok je problematické porovnávat' s inými štúdiami v zahraničí, pretože v našom prípade ide o štúdiu jedného regiónu s jednou vysokou školou.

Vyššia šanca ostat' pracovat' v regióne vysokej školy pre absolventov externého štúdia bola ovplyvnená hlavne rozhodnutiami nerezidentných absolventov. Absolventi externého štúdia zvyčajne študujú popri zamestnaní a ich motiváciou je zvýšit' úroveň vzdelania a získat' tak lepšiu vyjednávaciu pozíciu na trhu práce. Pomerne stabilný výsledok pri vyššej šanci na zotrvanie $v$ regióne sme zaznamenali v prípade obdobia od ukončenia štúdia. Čerství absolventi mali vyššiu šancu ostat' pracovat' $\mathrm{v}$ regióne vysokej školy. Teda čast' absolventov po získaní pracovných skúseností v regióne po prvých rokoch migruje za prácou do iných oblastí, pričom migrácia kulminuje približne po dvoch až troch rokoch (Haapanen a Tervo 2012).

\section{ZÁVER}

Hoci existuje pomerne bohatá analýza internej migrácie vysokoškolsky vzdelaných obyvatel'ov v SR, výskum v SR doposial' nereflektoval vzt'ah medzi miestom bydliska, miestom štúdia VŠ a miestom následného zamestnania. Ciel'om tohto článku bolo na základe štúdie migrácie absolventov Žilinskej univerzity v Žiline preskúmat' súvislost' medzi miestom vysokoškolského štúdia a miestom zamestnania po skončení vysokej školy. V článku sme sa zaoberali faktormi, ktoré ovplyvňujú rozhodnutie ostat' pracovat' po skončení školy na regionálnom trhu práce v mieste štúdia, resp. odíst' za prácou do iného regiónu.

Prevažná väčšina absolventov po ukončení štúdia odišla za prácou do iného regiónu, celkovo však narástol podiel jednotlivcov s vysokoškolským vzdelaním na regionálnom trhu práce. Tento efekt nastal zásluhou dôležitej časti nerezidentných 
absolventov, ktorí ostali po štúdiu pracovat' na regionálnom trhu práce $\mathrm{v}$ mieste štúdia. Teda môžeme konštatovat', že celkovo nastalo zvýšenie l'udského kapitálu na regionálnom trhu práce a všeobecne náš výskum poukázal na dôležitost' prítomnosti vysokej školy pre akumuláciu l'udského kapitálu v regióne. Podrobnejšia analýza ukázala, že dochádza k nahradzovaniu rezidentných absolventov nerezidentnými absolventmi z bližších pracovných trhov, a to tak z pohl'adu ich kvantity, ako aj kvality.

Náš výskum potvrdil vplyv klasických migračných faktorov absolventov, akými sú výška mzdy a charakteristiky jednotlivca (pohlavie, čas od ukončenia štúdia, absolvovaný študijný programu a forma štúdia). Vel'kost' vplyvu jednotlivých faktorov sa líši v závislosti od bydliska absolventa pri nástupe na vysokú školu. Domnievame sa, že rozhodovanie o migrácii je zároveň ovplyvnené aj sociálnymi väzbami a rozdielmi v informovanosti o pracovných možnostiach v mieste bydliska, čo naznačujú rozdielne výsledky v jednotlivých modeloch.

Naše závery v súčasnosti zahŕňajú len zistenia platné pre Žilinskú univerzitu v Žiline. Pre pochopenie vzt’ahu medzi migráciou a miestom vysokoškolského štúdia v SR je dôležité preskúmat' rozhodovanie absolventov aj iných vysokých škôl $\mathrm{v}$ iných regiónoch. Preto budúci výskum v tejto oblasti v SR by mal v prvom rade smerovat' k vybudovaniu údajovej základne pre takýto typ analýz prostredníctvom pravidelných dotazníkových prieskumov na univerzitách, prepájaním jednotlivých registrov obyvatel'ov alebo zahrnutím tejto témy do cenzu obyvatel'stva. Objasnenie tohto vzt'ahu môže priniest' dôležité poznatky o vplyve vysokých škôl na rozvoj regiónov, v ktorých pôsobia.

Táto práca bola podporovaná Agentúrou na podporu výskumu a vývoja na základe zmluvy č. APVV-14-0512. Autori by týmto chceli pod'akovat Dr.h.c. prof. Ing. Tatiane Črejovej, PhD., rektorke Žilinskej univerzity v Žiline, za podporu a propagáciu prieskumu na univerzite.

\section{LITERATÚRA}

AHLIN, L., THULIN, P., ANDERSSON, M. (2014). Market thickness and the early labour market career of university graduates: an urban advantage? Spatial Economic Analysis, 9, 396-419.

BECKER, G. (1964). Human capital: a theoretical and empirical analysis, with special reference to education. Chicago (University Press, Chicago).

BERCK, P., TANO, S., WESTERLUND, O. (2016). Regional sorting of human capital: the choice of location among young adults in Sweden. Regional Studies, 50, 757-770.

BEZÁK, A., (2006). Vnútorné migrácie na Slovensku: súčasné trendy a priestorové vzorce. Geografický časopis, 58, 15-44.

BJERKE, L., MELLANDER, Ch. (2017). Moving home again? Never! The locational choices of graduates in Sweden. The Annals of Regional Science, 59, 707-729.

BUENSTORF, G., GEISSLER, M., KRABEL, S. (2016). Locations of labour market entry by German university graduates: is (regional) beauty in the eye of the beholder. Review of Regional Research, 36, 29-49.

CIRIACI, D. (2014). Does university quality influence the interregional mobility of students and graduates? The case of Italy. Regional Studies, 48, 1592-1608.

CRESCENZI, R., HOLMAN, N., ORRU', E. (2017). Why do they return? Beyond the economic drivers of graduate return migration. The Annals of Regional Science, 59, 603627.

DAVANZO, J. S., MORRISON, P. A. (1981). Return and other sequences of migration in the United States. Demography, 18, 85-101. 
DUMONT, J. C., MARTIN, J. P., SPIELVOGEL, G. (2007). Women on the move: the neglected gender dimension of the brain drain. IZA Discussion paper No. 2090.

FAGGIAN, A., McCANN, P., SHEPPARD, S. C. (2007a). Human capital, higher education and graduate migration: an analysis of Scottish and Welsh students. Urban Studies, 44, 2511-2528.

FAGGIAN, A. McCANN, P., SHEPPEARD, S. C. (2007b). Some evidence that women are more mobile than men: gender differences in UK graduate migration behaviour. Journal of Regional Science, 47, 517-539.

FAGGIAN, A., RAJBHANDARI, I., DOTZEL, K. R. (2017). The interregional migration of human capital and its regional consequences: a review. Regional Studies, 51, 128143.

GLAESER, E. L., KALLAL, H. D., SCHEINKMAN, J. A., SHLEIFER, A. (1992). Growth in cities. Journal of Political Economy, 100, 1126-1152.

GRAVES, P. E. (1980). Migration and climate. Journal of Regional Science, 20, 227-237.

GURŇÁK, D., LAUKO, V., KRIŽAN, F. (2011). Aktuálne tendencie vývoja dochádzkových regiónov verejných vysokých škôl na Slovensku. Acta Geographica Universitatis Comenianae, 55, 39-66.

HAAPANEN, M., TERVO, H. (2012). Migration of the highly educated: evidence from residence spells of university graduates. Journal of Regional Science, 52, 587-605.

HALÁS, M., KLAPKA, P., BLEHA, B., BEDNÁR, M. (2014). Funkčné regióny na Slovensku podla denných tokov do zamestnania. Geografický časopis, 66, 89-114.

HERBST, M., KACZMARCZYK, P., WÓJCIK, P. (2014). Migration of graduates within a sequential decision framework: evidence from Poland. IZA Discussion Paper No. 8573. Bonn (IZA).

KIDD, M., O'LEARY, N., SLOANE, P. (2014). Should I stay or should I go? An investigation of graduate regional mobility in the UK and its impact upon early career earnings. IZA Discussion Paper No. 8325. Bonn (IZA).

KRABEL, S., FLÖTHER, Ch. (2014). Here today, gone tomorrow? Regional labour mobility of German university graduates. Regional Studies, 48, 1609-1627.

LAUKO, V., GURŇÁK, D., KRIŽAN, F., TOLMÁČI, L. (2011). Školstvo na Slovensku $v$ kontexte regionálnych disparit. Prešov (Vydavatel'stvo Michala Vaška).

MA, K. R., KANG, E.-T., KWON, O-K. (2017). Migration behaviour of students and graduates under prevailing regional dualism: the case of South Korea. The Annals of Regional Science, 58, 209-233.

McCANN, P. (2013). Modern urban and regional economics. Oxford (Oxford University Press).

NOVOTNÝ, L., PREGI, L. (2016). Selektívna migrácia podl'a vzdelania v migračne úbytkových funkčných mestských regiónoch Spišská Nová Ves a Gelnica. Acta Geographica Universitatis Comenianae, 60, 189-205.

RAUCH, J. E. (1993). Productivity gains from geographic concentration of human capital: evidence from the cities. Journal of Urban Economics, 34, 380-400.

ROBACK, J. (1982). Wages, rents, and the quality of life. Journal of Political Economy, 90, 1257-1278.

ROMER, P. (1986). Increasing returns and long-run growth. Journal of Political Economy, 94, 1002-1037.

REHẢK, Š., DŽUPKA, P., SEKELSKÝ, L., ŠEBOVÁ, M. (2015). Lokálne ekonomické vplyvy univerzít. Bratislava (Vydavatel'stvo EKONÓM).

SJAASTAD, L. A. (1962). The costs and returns of human migration. Journal of Political Economy, 70, 80-93.

ŠPROCHA, B. (2011). Vnútorná migrácia podl'a najvyššieho dokončeného vzdelania na Slovensku. Prognostické práce, 3, 213-246

ŠTATISTICKÝ ÚRAD SR (2017). Databáza DataCube, [Online]. Dostupné na: http:// datacube.statistics.sk/ [cit: 21-12-2017]. 
VENHORST, V., van DIJK, J., van WISSEN, L. J. G. (2010). Do the best graduates leave the peripheral areas of the Netherlands? Tijdschrift voor economische en sociale geografie, 101, 521-537.

VENHORST, V. van DIJK, J., van WISSEN, L. (2011). An analysis of trends in spatial mobility of Dutch graduates. Spatial Economic A nalysis, 6, 57-82.

\author{
Štefan R e hák, Ivana Dudová
}

\title{
WHO STAYS AND WHO LEAVES? MIGRATION DECISION OF THE GRADUATES FROM THE ŽILINA UNIVERSITY IN ŽILINA
}

Raising the level of human capital by providing higher education is considered to be the most important factor by which universities influence the development of the region. Individuals with a higher level of education are the carriers of new knowledge and the companies that employ them are more productive. However, the contribution of the individual university to the regional human capital depends on the migration of its graduates. The aim of the article was to examine the relationship between the location of studies and the location of employment, by analysing the factors influencing the decision to stay to work in the region of higher education, or to migrate into another region.

Our research is based on the data from the questionnaire survey of two cohorts of graduates from the Žilina University in Žilina. Approximately $87 \%$ of resident and $21 \%$ of nonresident university graduates work after completing their studies in the Žilina region. Using logistic regression, we analysed the factors that influence the migration decision of university graduates. Our research has confirmed the impact of wages on the migration decision. Graduates are attracted to the regions with higher wages. In addition, we have highlighted the important influence of gender, the graduate study programme and the form of studies. Women have a higher chance to remain in the university region after graduating. Gender differences are the result of a different degree of risk aversion that migration is associated with. The differences in migration probability between study programmes in technical sciences and social sciences and humanities are usually due to the differences in the spatial distribution of jobs and the extent to which the structure of study programmes at the university matches the needs of the regional labour market. Part-time students are more likely to stay in the region after graduation. The magnitude of the impact of each factor varies depending on the residence of the graduate when entering the college. Migration decisionmaking is also influenced by social ties and information on job opportunities at the place of residence.

Our findings currently included are only valid for the Žilina University in Žilina. In order to understand the relationship between migration and the location of studies in Slovakia, it is important to analyse the migration decisions of graduates from universities in other regions as well. Clarifying this relationship can bring important insights into the impact of universities on the development of their host regions. 
, 